\title{
ТЕОРЕТИКО-МЕТОДОЛОГІЧНІ ЗАСАДИ УДОСКОНАЛЕННЯ ВИКЛАДАННЯ ВОГНЕВОЇ ПІДГОТОВКИ У ВИЩИХ НАВЧАЛЬНИХ ЗАКЛАДАХ ЗІ СПЕЦИФІЧНИМИ УМОВАМИ НАВЧАННЯ
}

Ульянов О. І., Конєв О. Ю.

\begin{abstract}
У статті викладені основні методики вдосконалення викладання вогневої підготовки у вищих навчальних закладах зі специфічними умовами навчання. Запропоновано новий підхід до розробки вправ зі стрільби, а також поліцейських квестів для курсантів, які пройшли курс базової вогневої підготовки, з урахуванням специфіки їхньої подальшої професійної діяльності у відповідних практичних підрозділах Національної поліції (для дільничних офіцерів поліції, для оперуповноважених підрозділів кримінальної поліції, для слідчих).

Обірунтовано необхідними під час викладання вогневої підготовки у курсантів базові вправи зі стрільби, поряд із цим запропоновано разом зі швидкісними вправами включити до стрільб спеціальні вправи, розроблені з урахуванням напряму підготовки майбутніх поліцейських, зокрема дільничних офіцерів поліції, оперуповноважених кримінальної поліції, слідчих тощо.
\end{abstract}

Ключові слова: вогнева підготовка, тактична медицина, професійна підготовка, вогнепальна зброя, екстремальні умови, поліцейські квести.

В данной научной статье изложены основные методики совершенствования преподавания огневой подготовки, которые можно использовать при подготовке будущих полицейских в высших учебных заведениях со специфическими условиями обучения.

Предложен новый подход к разработке упражнений по стрельбе, а также полицейских квестов для курсантов, которые прошли курс базовой огневой подготовки, с учётом специфики их дальнейшей профессиональной деятельности в соответствующих практических подразделених Национальной полиции (для участковых офицеров полиции, для оперуполномоченных подразделений криминальной полиции, для следователей).

Обоснованы необходимыми во время преподавания огневой подготовки у курсантов базовые упражнения по стрельбе, наряду с этим предложено вместе со скоростными упражнениями включить в стрельбы специальные упражнения, разработанные с учётом направления подготовки будущих полицейских, в частности участковых офицеров полиции, оперуполномоченных криминальной полиции, следователей.

Ключевые слова: огневая подготовка, тактическая медицина, профессиональная подготовка, огнестрельное оружие, экстремальные условия, полицейские квесты.

This scientific article outlines the main methods of improving the teaching of fire training that can be used in training future police officers in higher educational institutions with specific learning conditions.

A new approach to the development of shooting exercises, as well as police quests for cadets who have completed basic fire training, taking into account the specifics of their future professional activity in the relevant practical police units (for district police officers, for criminal investigation police officers, for investigators).
It was substantiated the necessity of basic shooting exercises in the course of firearm training, among others it was proposed to include special exercises of shooting together with rapid fire exercises, geared towards the training direction of future police officers, in particular, local police officers, criminal intelligence investigators and investigators.

The appropriate training exercises were created on the basis of the experience gained and the analysis of mistakes committed by police officers in practice while using firearms. The above-mentioned exercises should reflect the specificity of different police departments activity and must focus on skills progression for the professional use of firearms by future policemen. It will provide an opportunity for the instructor to simulate a certain situation into an educational exercise, taking into account the peculiarities of using firearms by policemen in practice.

It was defined that conducting practical exercises in the form of a police quest in the educational establishments with specific training conditions is an effective mean of solidifying the theoretical knowledge and developing practical skills necessary for cadets in their future professional activity. Implementation of above-mentioned practical exercises will produce practical component in the course of cadets' teaching, their skills acquisition for completing tasks in both standard and non-standard situations, and, as a result, are obligatory conditions for successful practical activity.

Key words: fire training, tactical medicine, vocational training, firearms, extreme conditions, police quests.

Постановка проблеми. Значна частина повсякденної оперативно-службової діяльності в підрозділах Національної поліції здійснюється в умовах підвищеного ризику. Ця діяльність перш за все пов'язана з екстремальними ситуаціями під час боротьби правоохоронців із правопорушниками. На жаль, як показує практичний досвід, під час затримання правопорушників або транспортних засобів трапляються непоодинокі випадки, коли поліцейські отримують тяжкі поранення, іноді $з$ летальним результатом. Основними причинами таких тяжких наслідків стають тактично непрофесійні дії під час затримання правопорушників, а також грубі помилки у поводженні з вогнепальною зброєю.

Наявні численні дослідження причин втрат особового складу в ході виконання оперативно-службових завдань, що проведені на основі архівних кримінальних справ, матеріалів службових і прокурорських перевірок, свідчать про те, що непрофесійні дії поліцейських сприяли здійсненню проти них злочинних намірів з боку осіб, які вчиняють протиправні дії.

Практична підготовка поліцейських характеризується низкою особливостей, які необхідно враховувати під час викладання вогневої підготовки для курсантів у вищих навчальних закладах зі специфічними умовами 
навчання, таких як: стрільба на випередження, без ретельного прицілювання, в обмежений час; стрільба в русі; стрільба на коротких дистанціях.

Головним завданням навчальної дисципліни «Вогнева підготовка» $\epsilon$ формування у курсантів готовності до ефективного застосування вогнепальної зброї в ситуаціях, коли виникають до цього підстави, передбачені Законом України «Про Національну поліцію» [1].

Вогнева підготовка у вищих навчальних закладах зі специфічними умовами навчання $\epsilon$ одним із провідних предметів [2-4]. Уміння влучно та професійно володіти вогнепальною зброєю $є$ основою вогневої підготовки майбутніх офіцерів поліції. Актуальність вивчення цієї навчальної дисципліни полягає в тому, що кожен курсант зобов'язаний досконало володіти вогнепальною зброєю, що у майбутньому дасть змогу йому не тільки професійно виконувати свої обов'язки, але і в екстремальних випадках зберегти своє життя та життя інших людей від протиправних посягань злочинців.

Метою статті $\epsilon$ визначення та обґрунтування теоретико-методологічних засад удосконалення викладання вогневої підготовки у вищих навчальних закладах зі специфічними умовами навчання, що сприятиме виробленню у майбутніх поліцейських навичок щодо застосування вогнепальної зброї у різних стресових умовах та екстремальних ситуаціях, а також надання пропозицій щодо впровадження інноваційних методик.

Аналіз останніх досліджень і публікацій. Окремі аспекти з вироблення методичних рекомендацій щодо удосконалення викладання вогневої підготовки у вищих навчальних закладах МВС України досліджувалися у працях М. Ануфрієва, Г. Будагьянц, В. Волянського, В. Гурського, А. Жбанчика, І. Закорко, О. Комісарова, Ю. Корнійчука, О. Кузнецова, Д. Сіротченкова, В. Тимофєєва та інших провідних науковців.

Разом із тим питанню впровадження поліцейських квестів та елементів тренінгових технологій під час проведення занять з вогневої підготовки уваги приділено не досить, що і актуалізує зазначене дослідження.

Виклад основного матеріалу дослідження. У контексті досліджуваного питання слід зазначити, що Наказом МВС України № 50 від 26 січня 2016 року «Про затвердження Положення про організацію службової підготовки працівників Національної поліції України» визначено порядок планування, проведення та обліку занять, здійснення контролю знань, умінь та навичок осіб молодшого, середнього та вищого складу Національної поліції України. Відповідно до п. 6 зазначеного підзаконного нормативно-правового акта різновидами службової підготовки серед іншого є тактична та вогнева підготовка. Нагадаємо, що вогнева підготовка передбачає комплекс заходів, спрямованих на вивчення поліцейським основ стрільби з вогнепальної зброї, правомірного їі застосування (використання) та вдосконалення навичок безпечного поводження з нею, швидкісної та влучної стрільби по нерухомих і рухомих цілях, з різних положень, в обмежений час, у русі тощо [5]. Рівень володіння вогнепальною зброєю курсантами, їх знання нормативної бази щодо застосування цієї зброї зумовлює у майбутньому належне виконання ними своїх службових обов'язків як офіцерів поліції, а також створює основи для особистої безпеки і дотримання публічного порядку в нашій країні.
Вогнева підготовка як базовий складник службової підготовки майбутніх поліцейських передбачена навчальними планами у вищих навчальних закладах зі специфічними умовами навчання.

Мета викладання вогневої підготовки спрямована на те, щоб забезпечити майбутніх поліцейських необхідним комплексом знань, умінь і практичних навичок застосування теоретичних знань щодо подальшого прийняття правомірних рішень та психологічної готовності до дій у ситуаціях різних ступенів ризику, а також застосування вогнепальної зброї, у тому числі в екстремальних ситуаціях проведення спеціальних операцій із затримання правопорушників, самооборони, захисту громадян від протиправних посягань.

Окрім вищезазначеного наказу, ще один підзаконний нормативно-правовий акт, а саме Наказ МВС України від 26 квітня 2019 № 334 «Про затвердження Курсу стрільб для поліцейських та норм витрат боєприпасів, пострілів, вибухових пакетів і гранат поліцейськими під час проведення практичних стрільб», визначає порядок організації i проведення 3 поліцейськими структурних підрозділів центрального органу управління поліції, міжрегіональних територіальних органів Національної поліції та їх відокремлених підрозділів, територіальних органів поліції, установ, що належать до сфери управління Національної поліції, практичних стрільб із пістолета, штурмової гвинтівки (автомата), кулемета (ручного кулемета), ручного протитанкового і підствольного гранатометів, снайперської гвинтівки, помпової рушниці, практичних занять з кидання ручних гранат, а також умови та порядок виконання вправ зі стрільби (спортивних стрілецьких вправ з прикладної стрільби) та кидання ручних гранат і нормативів з вогневої підготовки [6].

Відзначимо, що в наказі передбачено навчальні тренувальні вправи зі стрільби. Вправа зі стрільби - це кількісно-якісний показник виконання поліцейським прийомів і дій з бойовою зброєю у межах тиру (стрільбища) [2, с. 77]. За загальним правилом вправи зі стрільби та кидання ручних гранат поділяються на три категорії: 1) перша категорія вправ - виконуються поліцейськими виключно під час навчання у ЗВО МВС, установах поліції та спрямовані на формування знань, умінь і навичок поводження зі зброєю під час стрільби: 2) друга категорія вправ - виконуються у ЗВО МВС, органах (підрозділах), установах поліції, зокрема на заняттях зі службової підготовки та на навчальних зборах, спрямовані на вдосконалення знань, умінь і навичок поводження зі зброєю під час стрільби: 3) третя категорія вправ - виконуються поліцейськими підрозділів поліції особливого призначення (у тому числі на навчальних збоpax), поліцейськими, які залучаються до проведення спеціальних (антитерористичних) операцій, та спрямовані на формування як індивідуальних, так і групових висококваліфікованих навичок поводження зі зброєю під час стрільби в екстремальних умовах. Під час виконання вправ цієї категорії поліцейські обов'язково забезпечуються відповідним екіпіруванням та засобами індивідуального захисту.

На наш погляд, заслуговує на увагу перша та друга категорії вправ, оскільки саме вони найчастіше передбачені навчальними планами у вищих навчальних закладах зі специфічними умовами навчання. Усі зазначені вправи зі стрільби є цілком досконалими та спря- 
мовані, зокрема, на прищеплення початкових навичок: - у стрільбі по нерухомій цілі в необмежений час; прицільної стрільби по нерухомій цілі в необмежений час; час;

стрільби з двох рук по нерухомій цілі в обмежений

ведення вогню із заміною магазину, а також на навчання стрільби по нерухомій цілі в обмежений час;

стрільби після фізичного навантаження по нерухомій цілі в обмежений час; стрільби з перенесенням вогню в обмежений час тощо.

Водночас зазначені вправи дають змогу курсантам набути:

знання правил і заходів безпеки;

основ стрільби;

- відомостей з внутрішньої і зовнішньої балістики;

- матеріальної частини зброї, боєприпасів та інших основних положень під час стрільби з вогнепальної зброї;

- вміння зробити технічно правильний постріл (правильне прицілювання, вибір району прицілювання, спуск курка з бойового взводу); правильне розміщення зброї і боєприпасів у спорядженні, вміння миттєво привести його в бойову готовність, вибір вогневої позиції і використання укриття; навички швидкого перезарядження (заміни магазинів) і самостійне швидке усунення виникаючих затримок, які ніхто не допоможе усунути в реальній бойовій обстановці;

- вміння ідентифікувати ціль і миттєво проводити юридичну оцінку ситуації; виконання вправ курсу стрільб (початкових, навчальних і контрольних) у різних умовах (у разі слабкого і достатнього освітлення, на різних дистанціях), спираючись на вміння в найкоротший час зробити постріл.

Безперечно, вищезазначені вправи $\epsilon$ базовими та необхідними під час викладання вогневої підготовки у курсантів, однак, на нашу думку, поряд із початковими та швидкісними вправами $\epsilon$ сенс включити до стрільб спеціальні вправи, розроблені з урахуванням напряму підготовки майбутніх поліцейських, зокрема дільничних офіцерів поліції, оперуповноважених кримінальної поліції, слідчих тощо.

Наказом МВС України № 900 від 20.09.2016 року регламентовано загальні правила щодо проведення стрільб для поліцейських різних підрозділів. Однак слід зауважити, що діяльність поліцейських кожного підрозділу Національної поліції під час виконання ними службових обов' язків має свої особливості, які впливають на застосування ними вогнепальної зброї у різних екстремальних ситуаціях. Практичний досвід показує, що в оперуповноважених блоку кримінальної поліції виникають ситуації із застосуванням вогнепальної зброї, які $\epsilon$ відмінними від ситуацій, в яких вогнепальну зброю застосовують дільничні офіцери поліції або слідчі. Це залежить від напрямів їхньої службової діяльності, поставлених перед ними задач та конкретних екстремальних випадків, в яких поліцейські застосовують вогнепальну зброю.

Вважаємо, що під час викладання вогневої підготовки у вищих навчальних закладах зі специфічними умовами навчання необхідно враховувати перш за все досвід та особливості застосування вогнепальної зброї поліцейськими різних підрозділів (дільничними офіцерами поліції, оперуповноваженими кримінальної поліції, слідчими, патрульними, ), які відрізняються між собою.
На наш погляд, під час викладання вогневої підготовки курсантам, які вже здобули початкову вогневу підготовку, доречним $\epsilon$ впровадження вправ зі стрільби, що максимально відображають специфіку діяльності поліцейських різних підрозділів на практиці. Наприклад, для підготовки майбутніх дільничних офіцерів поліції мають бути вправи, які відображають специфіку професійної діяльності дільничного офіцера поліції та ситуації, в яких він має право застосувати вогнепальну зброю. Відповідні вправи мають бути розроблені і для майбутніх фахівців підрозділів кримінальної поліції, і для слідчих.

Важливим моментом при цьому також буде врахування помилок, яких припускалися поліцейські (дільничні, оперуповноважені кримінальної поліції, слідчі, патрульні) під час застосування вогнепальної зброї.

Отже, на підставі отриманого досвіду та аналізу помилок, які були допущені на практиці поліцейськими під час застосування вогнепальної зброї, можна сформувати відповідні тренувальні вправи для їх виконання у розрізі вивчення останніми вогневої підготовки. Зазначені вправи мають максимально відображати специфіку діяльності поліцейських різних підрозділів на практиці та спрямовані на вироблення навичок щодо професійного застосування вогнепальної зброї майбутніми поліцейськими. Своєю чергою такий позитивний досвід дасть можливість інструктору моделювати певну ситуацію у навчальну вправу, враховуючи особливості застосування вогнепальної зброї поліцейськими на практиці, та помилки, яких вони припустилися під час такого застосування. Мета виконання таких тренувальних вправ - надалі уникнути допущення майбутніми поліцейськими зазначених вище помилок та набуття ними практичних навичок щодо професійного застосування вогнепальної зброї.

У цьому напрямі вважаємо за необхідне запропонувати під час навчання курсантів вогневої підготовки відпрацювання ними обов'язкових вправ, зокрема у кількості 6-8 (наприклад, 2 початкові, 2 швидкісні та 2 спеціальні вправи). Вважаємо за необхідне у майбутньому приділити максимальну увагу вправам зі стрільби за відповідними напрямами підготовки курсантів, які максимально відображають специфіку діяльності поліцейських різних практичних підрозділів, а також відпрацюванню спеціально розроблених поліцейських квестів: окремо для підготовки фахівців превентивної діяльності, окремо для кримінального блоку і для слідчих.

Слід зазначити, що проведення практичних занять у формі поліцейського квесту в закладах зі специфічними умовами навчання $\epsilon$ ефективним засобом закріплення теоретичних знань та розвитку практичних навичок, що необхідні курсантам у майбутній професійній діяльності.

Впровадження поліцейських квестів та елементів тренінгових технологій під час проведення занять з вогневої підготовки насамперед сприяє забезпеченню практичного складника навчання курсантів, набуттю ними навичок виконання завдань як у стандартних, так і нестандартних ситуаціях, що $є$ обов'язковими умовами успішної практичної діяльності.

Щодо механізму проведення поліцейських квестів з вогневої підготовки слід зазначити таке: завдання, яке отримує кожна з команд, має бути пов'язане із розв'язанням ситуаційного завдання та характеризува- 
тися особливостями практичної діяльності дільничних офіцерів поліції за напрямом підготовки фахівців для превенціі; оперуповноважених кримінального блоку для підготовки фахівців кримінальної поліції і т.д. Отже, на нашу думку, завдання, передбачені у поліцейських квестах з вогневої підготовки, мають перш за все відображати особливості практичної діяльності відповідного підрозділу Національної поліції для курсантів за напрямом їхньої професійної підготовки (дільничні офіцери поліції, оперуповноважені кримінального блоку, слідчі). Разом із тим під час складання завдань для поліцейських квестів з вогневої підготовки необов'язково визначати відстань під час стрільби або вихідне положення, з якого виконується вправа. Зазначені вправи з вогнепальної зброї у квесті мають бути змодельовані з урахуванням ситуативного завдання, яке відображає застосування вогнепальної зброї або майбутнім дільничним, або оперуповноваженим, або слідчим.

До вказаного слід додати, що у майбутньому поліцейські квести з вогневої підготовки можна проводити з урахуванням положень таких навчальних дисциплін, як тактико-спеціальна підготовка та тактична медицина, що у сукупності сприятиме виробленню у майбутніх поліцейських навичок не тільки щодо застосування ними вогнепальної зброї, але й щодо надання першої невідкладної долікарської допомоги, що зменшить кількість можливих жертв у тій чи іншій екстремальній ситуації.

На нашу думку, актуальним $\epsilon$ залучення до проведення навчальних занять з вогневої підготовки з курсантами вищих навчальних закладів зі специфічними умовами навчання поліцейських-практиків із різних підрозділів Національної поліції. Це можуть бути бінарні заняття як форма навчання за участю викладача-теоретика та практичного працівника. Мета бінарного заняття - створити умови практичного застосування знань, навичок та вмінь і надати можливість курсантам побачити результативність своєї роботи. Проведення бінарних занять забезпечує формування у курсантів цілісної системи уявлень про вогневу підготовку поліцейського із застосуванням практичних вправ.

Водночас позитивним моментом $\epsilon$ також взяття участі практичного працівника в організації та проведенні поліцейського квесту з вогневої підготовки як інноваційної форми навчання та ефективного засобу закріплення у курсантів теоретичних знань та практичних навичок.
Висновки. Удосконалення викладання вогневої підготовки у вищих навчальних закладах зі специфічними умовами навчання не має обмежуватися тільки положеннями відповідних наказів, воно потребує моделювання ситуацій 3 урахуванням практичного досвіду застосування вогнепальної зброї поліцейськими різних підрозділів Національної поліції. Такий підхід має бути відображений у формуванні відповідних квестів для курсантів з урахуванням практичного досвіду застосування вогнепальної зброї поліцейськими підрозділами Національної поліції.

\section{Література}

1. Про Національну поліцію : Закон України від 02.07.2015 року. URL: http://zakon0.rada.gov.ua/laws/ show $/ 580-19 /$ page?text=\%E1\%E5\%F1\%B3\%E4\%E8.

2. Вогнева підготовка : навчально-методичний посібник / Жбанчик А.В., Комісаров О.Г., Тимофєєв В.П., Сіротченков Д.Ю., Кузнецов О.І. Дніпро : ДДУВС, 2017. 149 с.

3. Ануфрієв М.І. Службова підготовка працівників органів внутрішніх справ : навчально-методичний посібник. Київ : РВВ МВС України, 2003. 440 с.

4. Будагьянц Г.Н. Огневая подготовка. Пути повышения профессионального мастерства : учебное пособие / Г.Н. Будагьянц, И.П. Закорко. Луганск : РИО ЛАВД, 2005. $460 \mathrm{c}$.

5. Про затвердження Положення про організацію службової підготовки працівників Національної поліції України : Наказ Міністерства внутрішніх справ України № 50 від 26 січня 2016 року. URL: http://zakon3.rada.gov.ua/laws/ show/z0260-16\#n17.

6. Про затвердження Курсу стрільб для поліцейських та норм витрат боєприпасів, пострілів, вибухових пакетів і гранат поліцейськими під час проведення практичних стрільб : Наказ МВС України № 334 від 26 квітня 2019 року.

Ульянов О. І., кандидат юридичних наук, доцент, професор кафедри тактико-спеціальної, вогневоі та фізичної підготовки Одеського державного університету внутрішніх справ

Конєв О. Ю., кандидат юридичних наук, доцент, доцент кафедри тактико-спеціальної, вогневої та фізичної підготовки

Одеського державного університету внутрішніх справ 